\title{
Solid Waste management in Kuala Selangor and Sabak Bernam
}

\author{
Dr. Shakiba $\mathrm{N}^{1}$, Shagar $\mathrm{P}^{2}$, Dr. Hod $\mathrm{R}^{3}$ \\ ${ }^{I}$ (Department of Community Medicine, UKM Medical Centre, Malaysia) \\ ${ }^{2}$ (Department of Community Medicine, UKM Medical Centre, Malaysia) \\ ${ }^{3}$ (Department of Community Medicine, UKM Medical Centre, Malaysia)
}

\begin{abstract}
The disposal of solid waste has become an important issue in modern and developing countries like Malaysia. This was a cross-sectional study using secondary data from a public survey (January-December 2011). A total of 153 households from 2 villages in Selangor (75.2\% from Kuala Selangor \& 24.8\% from Sabak Bernam) have completed data on solid waste management. Dependent variables include methods of solid waste disposal. Independent variables were the type of the houses, the district and the family income. To manage the solid waste, $44.4 \%$ sanitary landfill and $55.6 \%$ chose other ways (burying, burning, etc). In our sample $47.7 \%$ was in traditional houses but $9.6 \%$ of them chosen sanitary landfill and $90.4 \%$ chosen other disposal methods $(P<0.001)$. From total respondents $52.3 \%$ were in modern houses which $76.3 \%$ of them had sanitary landfill and $23.8 \%$ had the other methods $(P<0.001)$. There were no difference between the living district and the disposal method $(P>0.05)$. There were no association between the households' income and the solid waste disposal method ( $P>0.05)$. Majority of modern house families used sanitary landfill but families in traditional houses $90 \%$ used non-authorized ways. More studies need to probe further why sanitary landfills were not successful in this area.
\end{abstract}

Keywords: Municipal solid waste management- sanitary land fill- solid waste facilities.

\section{Introduction}

As long as people are living in community settlements, collecting and dumping of rubbish has been a prominent issue. ${ }^{1}$ Thereby it is of great concern to know what solid waste (SW) is and how to manage it. It is important to distinguish "solid waste" as a common term from "waste". Solid waste requires systematic management to minimize undesirable impacts on people and their environment. ${ }^{2}$

During the early days, solid waste management consists of digging pits near temporary or permanent residential area and burying the refuse ${ }^{3}$ It is important to control the leachate within the landfill site to prevent the surface water and ground water pollution. ${ }^{4}$ Landfills also can cause air pollution with making Methane and greenhouse gases which need to be managed. ${ }^{5}$ After a while this phenomenon became an interest to archaeologists, health care system and civil engineers to determine the quality of life in residential areas, growing populations and rapid increase in urban lifestyles that made this solid waste practice unsustainable. People who did not find an appropriate place to bury their rubbish would throw it into the empty spaces or watercourses. This encouraged rodents to contaminate the water and jeopardized the people's health. As a consequence, authorities enforced legislation for proper collection and disposal of solid waste, and it is a form of systematic structuring and institutionalization of solid waste management. ${ }^{6,7,8}$

A vast number of human activities can generate solid wastes. ${ }^{9}$ Large amount of solid waste are produced by agriculture and mining industries, but these wastes generally have less impact on the majority of population and are not included in our study. Conspicuously improper solid waste management has negative impact on people's lives as well as the negative effect on the environment. These are the reasons that make municipal solid waste management an important issue. ${ }^{10}$ The municipal or other government authorities is responsible for the collection and disposal of the wastes which originated from houses, streets, shops, offices, factories, hospitals and other institutions. ${ }^{11}$

The vision of Malaysia for 2020 is to become a fully developed nation. Thus Malaysia has a lot to do for an appropriate solid waste management. ${ }^{12}$ The authorized solid waste management in Malaysia is still based on the land fill. To improve the services and the coverage of rural area as well as urban areas we need to know the rural proportion of community who actually use landfill as an authorized sanitary SWM. ${ }^{13}$ The best district to conduct the study would be the one that generates most solid waste per day. If we take a look at daily solid waste generation among the states of Malaysia, Selangor stood out as the most amount of solid waste generation (Fig 1).

Thus, in this study our research question was "What is the proportion (\%) of authorized solid waste management in Sabak Bernam and Kuala Selangor?" 


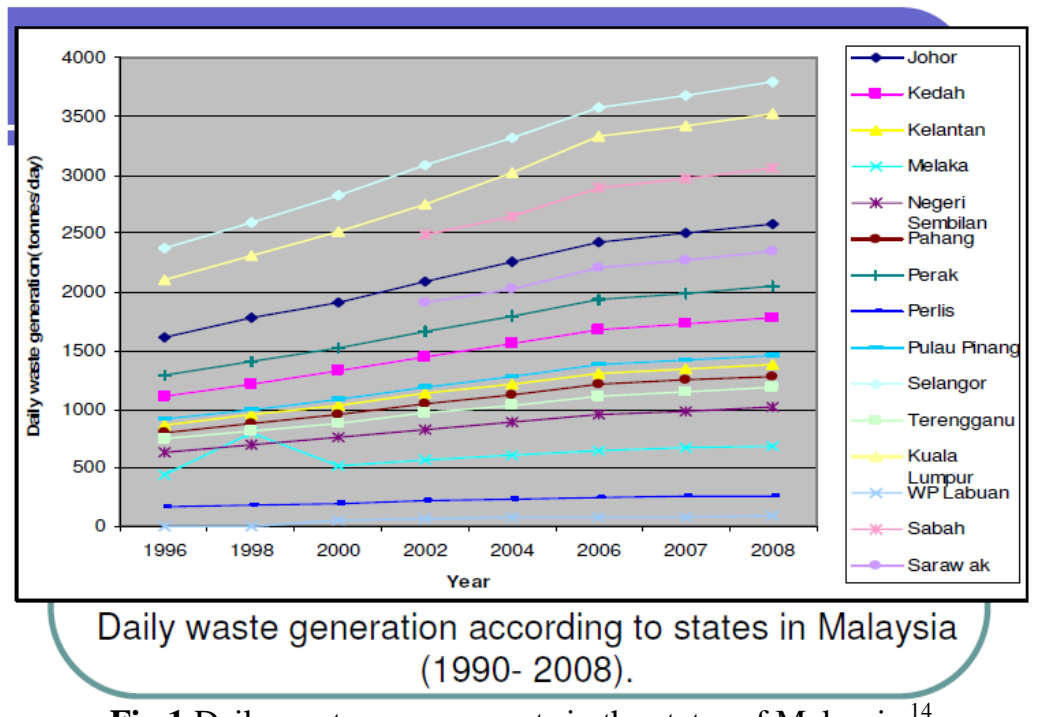

Fig 1 Daily waste managements in the states of Malaysia ${ }^{14}$

\section{Methods}

A vast number of studies in solid waste management have been conducted. Depending on the objectives, the studies had differing results. Hence, the debate surrounding the effect of solid waste management on the government policies and the environmental hygiene continues. This research aimed to determine the percentage of participation of two rural area of Selangor state, regarding proper Solid Waste Management using a cross-sectional design approach.

According to Shafik and Bandyopadhyay in 1994; Alexander, Judd H. in 1993; Beede and Bloom in 1995; and Johnstone and Labonne in 2004: the minimum solid waste generation per day for even the poorest people is around 0.3-0.4 kilograms every day. If the population increases by $1 \%$, it will be associated with $1.04 \%$ increase in generating solid waste. If the income increases $1 \%$ per capita, it is related to $0.34 \%$ increase in solid waste generation. ${ }^{15,16,17,18}$

The hypothesis for this study suggests two points; first, there is a difference in Solid Waste Management between traditional houses and modern houses in the two study areas, second, there is an association between income of the residents and Solid Waste Management.

The secondary data extracted from a large community survey which was conducted to perform situational analysis of the current health status of the population in Sabak Bernam and Kuala Selangor from January to December 2011. Only 153 have completed the variables of the study which were the solid waste management variables.

The independent variable was solid waste management which was divided to two types; 1) Authorized solid waste management, 2) The other ways of solid waste management (for example; burning, burying, recycling the biologic wastes to use as fertilizer, throwing into the rivers, leaving it on the street or any empty place).

There were three independent variables; 1) The types of the houses which were categorized as traditional or modern houses, 2) Income of the household, 3) District.

The secondary data which has been used in this study was collected from 2 villages; Kuala Selangor district and Sabak Bernam district from January to December 2011.

To analyze the data 'Statistical Package for Social Sciences' (SPSS) Version 19.0 has been used. With this software the descriptive and analysis statistic data has been computed.

\section{Results}

Majority (72.5\%) of the participants was from Kuala Selangor and (24.8\%) were from Sabak Bernam. 
Table 1 Respondent information

\begin{tabular}{clc}
\hline & $\mathrm{N}(153)$ & $\%$ \\
\hline Participants from districts & 38 & \\
Sabak Bernam & 115 & 75.8 \\
Kuala Selangor & & \\
The kind of the houses & 73 & 47.7 \\
Traditional & 80 & 52.3 \\
Modern & & \\
Solid waste management & 68 & 44.4 \\
Authorized & 85 & 55.6 \\
Other ways & & \\
\hline
\end{tabular}

Table 1 also reveals the percentages of people who are living in modern houses $(52.3 \%)$ are slightly more than those who are living in traditional houses (47.7\%). Among these variables the authorized solid waste management $(44.4 \%)$ is clearly lower than the other ways of solid waste management $(55.6 \%)$.

Table 2 shows the participation of 2 rural area of in Selangor state in proper Solid Waste Management. The result of Chi Square analysis indicates people who are living in modern houses $76.3 \%$ are using authorized way to manage their solid waste in comparison with people who are living in traditional houses which just $9.6 \%$ of them are using authorized solid waste management. Thus the residents of modern houses are more likely to use authorized solid waste management compare to traditional house residents $(\mathrm{P}<0.05)$.

Table 2 Univariate analysis of association between types of the houses and Solid Waste Management Solid waste management, n (\%). (* Chi-square test)

\begin{tabular}{clllll}
\hline & Authorized & Others & $\mathrm{X}^{2^{*}}$ & df & P-value \\
\hline Type of houses & & & & & \\
Traditional houses & $7(9.6 \%)$ & $66(90.4 \%)$ & 68.694 & 1 & $<0.001$ \\
Modern houses & $61(76.3 \%)$ & $19(23.8 \%)$ & & & \\
& & & & \\
District & $20(52.6 \%)$ & $18(47.4 \%)$ & 1.372 & 1 & 0.241 \\
Sabak Bernam & $48(41.7 \%)$ & $67(58.3 \%)$ & & & \\
Kuala Selangor & & & & \\
\hline
\end{tabular}

The result in table 2 also shows there is no difference in solid waste management between Sabak Bernam and Kuala Selangor district (P>0.05) (Fig 2).

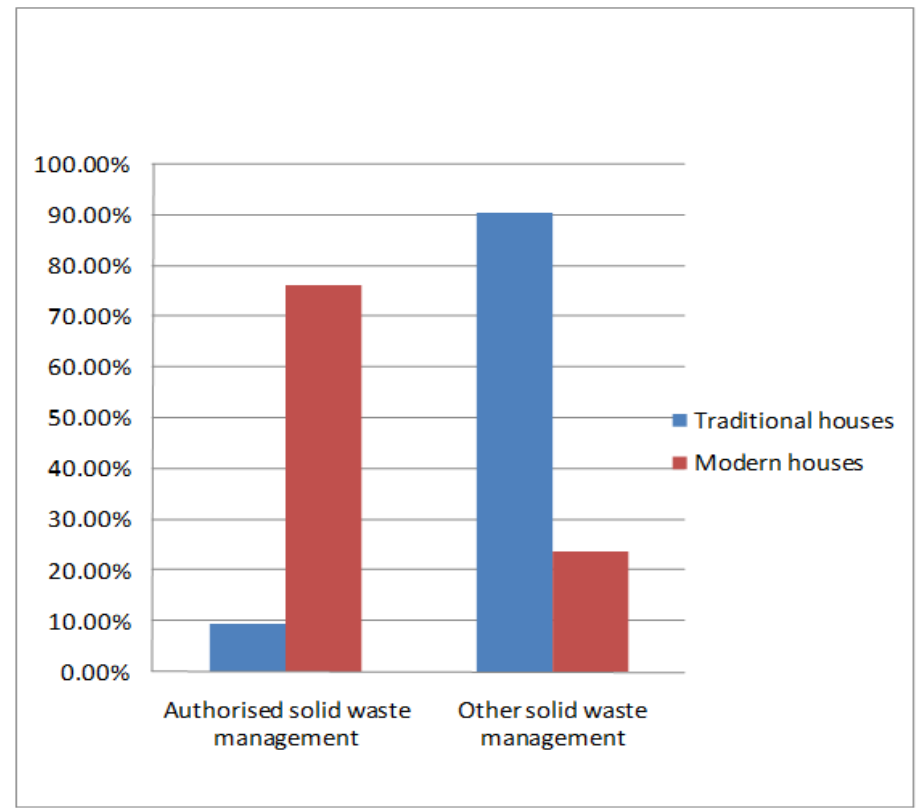

Fig 2 Solid Waste Management and types of houses; a comparison between Kuala Selangor and Sabak Bernam 
According to the results of the U Mann-Whitney Test analysis, there is no association between the way of solid waste management and the income of the households $(\mathrm{P}>0.05)$ (Table 3$)$.

Table 3 Compare sums of ranks of income (U Mann-Whitney Test)

\begin{tabular}{cllll}
\hline & Mean Rank & U Mann-Whitney & Z & P \\
\hline Solid waste management & & & & \\
Authorized & 75.01 & 2755.0 & -0.497 & 0.619 \\
Others & 78.59 & & & \\
\hline
\end{tabular}

\section{Discussion}

Our findings showed the amount of households' income was not associated with the way that they have chosen for their solid waste disposal. These findings are similar to previous study in China was achieved. According to the World Bank (2004) the U.S. in 2004 became the second world's largest municipal solid waste (MSW) generator after China. In 2004, the urban areas of China generated about 190 million tons of MSW. Considering China's relatively low level of per capita GDP and that over $56 \%$ of population still live in rural areas, the projected future MSW generation in 2030 for this country will be up to 480 million tons. ${ }^{19}$ In China as the economy level is rapidly developing, the amount of municipal solid waste generation is rising as well. The average of the annual increase rate of municipal solid waste generation in China is about 3.7\%, per capital. In 2002 it has reached $1 \mathrm{~kg}$ per day per person. No country has ever experienced such a large and rapid increase in waste generation. Rather than generating all this amount of MSW in China, Huang et al. in 2006 have found that less income families are even more eager to pay for their solid waste to be managed under the authorized system. ${ }^{20}$

Another finding of this study reveals; the residents of modern houses mostly choose the authorized way of solid waste management compare to people who live in traditional houses. The modern life style makes the availability of the personal choices of solid waste management so narrow. To explain this issue clearly we need to have some more information on the growth speed of generating solid waste in Malaysia. The current daily generation of municipal solid waste in Malaysia is approximately 30000 tones which mostly are managing with being filled up in some lands (landfills). This situation creates the crucial need for improved landfilling practices, as sustainable landfilling technology is yet to be achieved here. The objective of this paper is to identify and evaluate the development and trends in landfilling practices in Malaysia. In 1970, the disposal sites in Malaysia were small and prevailing waste disposal practices was mere open-dumping. This network of relatively small dumps, typically located close to population centers, was considered acceptable for a relatively low population of 10 million in Malaysia. In the 1980s, a national program was developed to manage municipal and industrial wastes more systematically and to reduce adverse environmental impacts. The early 1990s saw the privatization of waste management in many parts of Malaysia, and the establishment of the first sanitary landfills for MSW and an engineered landfill (called "secure landfill" in Malaysia) for hazardous waste. A public uproar in 2007 due to contamination of a drinking water source from improper landfilling practices led to some significant changes in the government's policy regarding the country's waste management strategy. Parliament passed the Solid Waste and Public Cleansing Management (SWPCM) Act 2007 in August 2007. Even though the Act is yet to be implemented, the government has taken big steps to improve waste management system further. The future of the waste management in Malaysia seems somewhat brighter with a clear waste management policy in place. There is now a foundation upon which to build a sound and sustainable waste management and disposal system in Malaysia. ${ }^{21,22}$

A sanitary landfill project in the Selangor State Government (SSG) have cost RM140 million in Mukim Jeram, Selangor for the disposal of municipal solid waste (MSW) with the lifespan of approximately 10 years from 2007 to receive about 1,000 to 1,500 tons of waste per day.

Landfill challenges include 2 main issues; one is highly mixed waste environmental impact which includes: water pollution, land contamination, air pollution. ${ }^{23}$ Second one is hazardous waste health risks which include: scavengers, pets, disease outbreak. ${ }^{24}$

Furthermore, Low income countries like Myanmar, Vietnam and Laos in average are making $0.64 \mathrm{~kg}$ solid waste per capita per day which is a low waste generation rate in comparison with the middle income countries like Indonesia, Philippines, Thailand and Malaysia which are making $0.73 \mathrm{~kg}$ solid waste per capita per day. It has been estimated that by 2025 in Asia especially in countries such as Malaysia, China and South Korea the waste generation would be increased up to 1.8 million tons of waste per day. ${ }^{25}$ There for now landfill can be still a suitable management for solid waste in Malaysia but for further planning the modernized solid waste management should be considered by the authorities. ${ }^{26}$ In early future Malaysia needs to concentrate on other ways of managing solid waste such as source reduction, recycling and waste combination. ${ }^{27}$ 
One of the principal issues in this study is about some residents who are not using authorized SWM because of some reasons like delaying in authorized solid waste transportation. This issue could be related to the lack of the proper logistics to ensure a desired SWM. ${ }^{28}$ According to Malaysian Digest, "Selangor Solid Waste Management Complaint Centre"; Menteri Besar Tan Sri Abdul Khalid Ibrahim told media on 24 December, 2011, Kuala Selangor: "A complaints center on solid waste management in Selangor will be established next year." This decision was made to answer complains of Selangor residents about the poor delivery collection of waste system from households. Despite all these effort as we can see from the result of this study some portion of residents of these districts was not using authorized SWM. Thus authorized SWM needs to be promoted. Some more research studies need to be conducted to recognize the reasons of failures in authorized SWM. ${ }^{29}$

In this study the limitation of the available information made an informational bias. We should remember that the income of the households is not a single factor. In other word there is a confounder factor which has a direct effect on the SWM method which has been chosen by residents. This confounder factor is the quality and disposability of the authorized services especially in rural areas. One of the major problem is the local government authorities are not capable of providing an adequate solid waste management system. ${ }^{30}$ This is not just an issue in developing countries. For instance in the USA there is still some challenges regarding to access of low income communities to a regular and proper garbage removal. Norton JM in 2007 indicated in North Carolina the solid waste facilities are disproportionately located in the low wealth communities. This shows the demand of new facilities to take an action and promote the environmental justice in these vulnerable communities. ${ }^{31}$ In developing countries like Malaysia this issue is prominent. Low collection coverage and no regular services to collect the waste, open dumping and burning the waste without air and water pollution control, the breeding of vermin, and the control of waste picking or scavenging are some of the considerable problems. ${ }^{32,33}$ Some studies which have been done by Coitreau (1984, 1994); Thomas Hope(1998); Schübeler (1996) and Bartone (2000); showed that even some cities which are spending a vast portion of their municipal revenues on waste management but still they fail to keep going with the scope of the problem. ${ }^{34,35,36}$ Senkoro (2003) revealed that $<30 \%$ of urban residents in many African countries have an access to a proper garbage removal. ${ }^{37}$

\section{Conclusion}

This study gives an over view for the further pilot studies and health promotion activities in these 2 rural area of Selangor. As a general conclusion we should think of the future that developing countries will face a greater challenge in the management of their solid wastes. According to previous studies the principal reason is the urbanization and improving the economy level.

Collecting, processing and disposing municipal solid wastes practices in developing countries like Malaysia are considered to be least efficient. Poor solid waste management in both developed and developing countries is a major threat to environmental health quality, and effects the quality of life, particularly in the poorer residents areas for both urban and rural vulnerable population. In the other hand very limited funds from the governments allocated for SWM in small towns can make the management of the solid wastes more complex. More studies need to be done on this issue, so that it will enable us to plan strategies in order to achieve 2020 vision and mission of Malaysia.

\section{Acknowledgements}

I would like to thank Dr. Rozita Hod my supervisor for all her advices in all steps of this study as well as associated professor Dr. Zaleha MD Isa and Professor Dr. Noor Hashim for their comments and recommendations.

\section{References}

[1] United Nations Development Programme (UNDP) Malaysia, Malaysia developing waste management model for Penang, (February 2008), ISBN 983-3904-08-2.

[2] S. Syed, Solid and liquid waste management, Emirates Journal for Engineering Research, review article, 11(2), 2006, 19-36.

[3] G. Tchobanoglous, H. Theisen and S. A. Vigil, Integrated solid waste management, engineering principals and management issues, New York, Mc Graw- Hill international edition, 1993.

[4] Environmental guidelines, solid waste landfills, Environment protection authority New South Wales, January 1996.

[5] San Diego air pollution control district, solid waste assessment for Otay Valley/Annex landfill, San Diego, CA, December 1988.

[6] R. Waite, Household waste recycling, London, Earth scan, 1995.

[7] A. Jarrah, L. Omar and A. Q. Hani, Municipal solid waste landfill siting using intelligent system, waste manasge, 26, 2005, 299.

[8] T. V. Ramachandra, Management of solid waste, Center for ecological science, Indian institute of science, Bangalore, India, 2006.

[9] M. Aljaradin and M. Kenneth, Environmental impact of municipal solid waste landfills in semi-arid climate study Jordan, The open waste management journal, 5, 2012, 28-39.

[10] R. Leete, Malaysia, from Kampung to Twin Towers, 50 Years of Economic and Social Development (Oxford Fajar: Shah Alam, Malaysia 2007).

[11] Z. Anwar, Solid Waste and Public Cleansing Management Corporation Bill, Development, Government of Malaysia (Oxford Fajar, Shah Alam, Malaysia, DR: 25/2007). 
[12] M. Nakamura, Challenges and future prospect of solid waste disposal in Malaysia, in WTE 2000 future prospect and challenges of converting solid waste to energy, 9 October 2000.

[13] Z. Anwar, Solid Waste and Public Cleansing Management Corporation Bill, Development, Government of Malaysia (Oxford Fajar, Shah Alam, Malaysia, DR: 26/2007).

[14] P. Agamuthu, Daily waste managements in the states of Malaysia, Journal of Biological Sciences, University of Malaya, 6(3), 2008, $102-121$

[15] N. Shafik, S. Bandyopadhyay, Economic Development and environmental quality, An econometric analysis, Oxford Economic Papers , (46), 1994, 757-773.

[16] Alexander, H. Judd, The origins of municipal solid waste, The relations between residues from packaging materials and food, World Resource Institute, Waste Management \& Research, (7), 1993, 103-14.

[17] D. N. Beede, D. E. Bloom, The economics of municipal solid waste, The World Bank Research Observer, 10(2), 1995, 113-150.

[18] N. Johnstone, J. Labonne, Generation of Household Solid Waste in OECD countries, An empirical Analysis Using Macroeconomic Data. Land Economics, 80(4), 2004, 529-538

[19] World Bank Toolkit, Social Assessment and Public Participation in Municipal Solid Waste Management, 2004, URL: http://www.worldbank.org/urban/uswm/socialassesstoolkit.pdf

[20] C. J. Huang, Y. H. Ho, Willingness to pay for waste clearance and disposal, results of the Taichung city study, The Business Review, Cambridge, 4(2), Dec 2005, 136-141.

[21] M. H. Isa, F. A. H. Asaari, N. A. Ramli, S. Ahmad, Solid waste collection and recycling in Nibong Tebal, Penang, Malaysia, a case study, Waste Manage Res, 23, 2005, 565-570, 2007.

[22] M. O. Saeed, M. N. Hassan, M. A. Mujeebu, Development of municipal solid waste generation and recyclable components rate of Kuala Lumpur, Perspective Study, E-journal, Respiratory @ USM 2008, URL: http://eprints.usm.my/13187/

[23] J. A. Herzstein, W. B. Bunn III, L. E. Fleming, J. M. Harrington, J. Jeyaratnam and I. R. Gardner, Environmental hazards and population, International occupational and environmental medicine, Solid waste, York university, 38, 2012, 620-632

[24] N. Kungskulniti, P. Chompusakdi, F. D. Miller and K. R. Smith, Solid waste scavenger community, an investigation in Bangkok, Thailand, Asia Pacific Journal of Public Health, 5(1): 54-56, 1991.

[25] D. Badgie, M. A. A. Samah, L. A. Manaf and A. B. Muda, Assessment of municipal solid waste composition in Malaysia, management, practice and challenges, Polish Journal of Environmental studies, 21(3), 2012, 539-547.

[26] Worldwide Landfills Sdn. Bhd., Detailed environmental impact assessment (DEIA), conceptual design and engineering consultancy service for the proposed Jeram and engineering consultancy service for the proposed Jeram sanitary landfill (JSL), MS ISO 9001:2000, December 2010, REG.NO. AR 2636.

[27] Environmental quality act, Environmental quality act, federal subsidiary legislation, Environmental quality act $1974,1989$.

[28] L. K. Aziale and E. A. Adjei, Logistic Challenges in Urban Waste Management in Ghana, A case of Tema Metropolitan Assembly, European Journal of Business and Management, 32(5), 2013, 116-128.

[29] C. R. Bartone, The role of the private sector in developing countries, Keys to success, Paper presented at ISWA Conf on Waste Management - Role of the Private Sector, Singapore, September 1995, 24-25.

[30] D. Badgie, Solid waste management system in the Kanifil municipal council (KMC), the Gambia, MSc thesis, University Putra Malaysia (UPM), 2011.

[31] J. M. Norton, the challenges of solid waste management, North Carolina Medical Journal, Number 2, 2011 ,Volume 72.

[32] P. Modak, Y. Jiemian, Y. Hongyuan and C. R. Mohanty, Municipal solid waste management, turning waste into resources, Shanghai manual, a guide for sustainable urban development in the 21rst century (U N Habitat, Chapter 5, 2009).

[33] H. Ogawa, Sustainable solid waste management in developing countries, WHO Western Pacific regional environmental health center (EHC), Kuala Lumpur, Malaysia, 7th ISWA International Congress and Exhibition, 2008, Parallel Session 7.

[34] S. J. Cointreau, Environmental Management of Urban Solid Wastes in Developing Countries, A Project Guide. Washington, DC: Urban Development Department, World Bank, S.1982.

[35] T. Hope, Solid waste management, critical issues for developing countries, Kingston, Canoe Press, 1998.

[36] P. Schubeler, Conceptual framework for municipal solid waste management in low-income countries, United Nations Development Program, UMP Working Paper Series no. 9. St. Gallen, Switzerland, 1996, SKAT, P.

[37] C. R. Bartone, Strategies for Improving Municipal Solid Waste Management, Lessons from World Bank Lending and CWG Activities, Workshop on Planning for Sustainable and Integrated Solid Waste Management, Manila, Urban Management Division, World Bank, Washington, DC September 2000, 18-22. 